\title{
EVALUASI PROGRAM PENILAIAN KINERJA SISWA SMK DALAM PELAKSANAAN PRAKERIN
}

\author{
Dila Umnia Soraya \\ Mardji \\ Syarif Suhartadi
}

\begin{abstract}
Abstrak: Tujuan penelitian ini untuk mengevaluasi program penilaian kinerja UPTPK Singosari, yang meliputi: (1) input: kualitas penilai, siswa, instrumen penilaian, dan metode penilaian; (2) proses penilaian; dan (3) hasil penilaian kinerja. Subjek penelitian yaitu instruktur, asisten instruktur, dan siswa Jurusan Listrik. Pengumpulan data dengan lembar angket dan lembar pengamatan dokumen, dianalisis dengan teknik statistik deskriptif. Hasil penelitian menunjukkan: (1) input: kualitas penilai telah sesuai, kualitas siswa kurang sesuai, kualitas instrumen penilaian cukup sesuai, dan kualitas metode penilaian sesuai, (2) kualitas proses penilaian telah sesuai, dan (3) kualitas hasil penilaian kinerja sangat sesuai.
\end{abstract}

Kata-kata Kunci: evaluasi, penilaian kinerja, prakerin

\begin{abstract}
Evaluation of Program Performance Assessment of Student SMK Prakerin in Implementation. The purpose of this study was to evaluate the performance appraisal program in UPT-PK Singosari, including: (1) inputs: the assessor's quality, student, assessment instrument, and assessment method, (2) assessment process, and (3) performance assessment result. The subjects of this study were the instructor, instructor's assistant, and electrical students at vocational high school Merdeka Lawang. Data were collected by questionnaire and observation sheet, and analyzed by descriptive statistics. The results showed that: (1) inputs: the assessor's quality was appropriate, the quality of the student was less satisfactory, the quality of assessment instrument was relatively appropriate, and the quality of assessment method was acceptable, (2) the quality of assessment process reached the standard, and (3) the quality of performance evaluation was very appropriate.
\end{abstract}

Keywords: evaluation, performance appraisal system, apprenticeship

$\mathrm{P}$

endidikan kejuruan merupakan pendidikan yang mempersiapkan peserta didik terutama untuk dapat bekerja dalam bidang tertentu (Depdiknas, 2004: 8). Berkaitan dengan itu, Sekolah Menengah Kejuruan (SMK) memiliki peran besar dalam mencetak lulusan berkualitas de- ngan keterampilan dan kreativitas tinggi agar mampu bersaing di dunia kerja. Wujud peran SMK dalam meningkatkan kualitas sumber daya manusia yaitu melalui kegiatan Praktik Kerja Industri (Prakerin). Melalui program Prakerin, siswa dapat mengembangkan keterampilan de-

Dila Umnia Soraya adalah Dosen Jurusan Teknik Elektro Fakultas Teknik Universitas Negeri Malang. Email: dila.umni4s@gmail.com. Mardji dan Syarif Suhartadi adalah Dosen Jurusan Teknik Mesin Fakultas Teknik Universitas Negeri Malang. Alamat Kampus: Jl. Semarang No. 5 Malang 65145. 
ngan berbagai pengalaman kerja di industri tempat Prakerin. Bentuk kegiatan pengembangan keterampilan tersebut ditunjukkan dalam sebuah prestasi kerja atau kinerja Prakerin.

Selain memperhatikan mutu perencanaan dan pelaksanaan Prakerin, kegiatan penilaian terhadap kinerja siswa praktikan juga merupakan hal yang tidak kalah penting untuk dilakukan. Asumsi yang mendasari pentingnya penilaian kinerja, yaitu setiap orang mempunyai keinginan mengembangkan kemampuan kerjanya, mendapat penghargaan atas kualitas kerjanya, dan mengetahui karir yang mampu mereka peroleh dengan kinerja baik (Sedarmayanti, 2010: 265). Tujuannya untuk memperbaiki atau meningkatkan kualitas kerja sumber daya manusia sebuah industri (Mangkunegara, 2010: 10).

Rangkaian kegiatan penyusunan sistem penilaian kinerja tidak boleh dianggap mudah. Sistem penilaian kinerja memberikan gambaran secara tepat mengenai kinerja siswa. Penilaian tidak hanya ditujukan untuk memperbaiki kinerja yang buruk tetapi dapat mendorong siswa untuk bekerja lebih baik. Kegiatan siswa harus diperhatikan, diamati, dan dinilai oleh pembimbing di industri. Siswa harus mendapat sosialisasi mengenai prosedur penilaian kinerja. Instrumen penilaian kinerja ditandatangani oleh penilai, siswa prakerin sebagai pihak yang dinilai, dan atasan penilai sebagai saksi. Siswa diberi kesempatan mendiskusikan hasil penilaian kinerja mereka. Hal ini bertolak belakang dengan kenyataan yang terjadi di Jurusan Listrik, UPT-PK Singosari. Prosedur penilaian kinerja tidak disosialisasikan kepada siswa dan siswa tidak diberikan kesempatan untuk mendiskusikan hasil penilaian kinerjanya.

Cara seperti ini bertolak belakang dengan sifat penilaian kinerja yang terbuka (Sedarmayanti, 2010: 273). Padahal penting mengijinkan pihak yang dinilai mengetahui bagaimana hasil penilaian kinerja dan pilihan apa yang tersedia sebagai alternatif jika mereka tidak setuju dengan hasil penilaian (Ambarwati, 2002: 95).

Metode penilaian yang digunakan sebatas tes tulis dan observasi, tes lisan hanya beberapa kali dilakukan. Kegiatan observasi yang dilaksanakan juga bersifat insidental dan bebas tanpa pedoman observasi. Penggunaan metode penilaian dan waktu penilaian sering tidak konsisten. Beberapa bagian penting dalam instrumen penilaian kinerja yang seharusnya ada tetapi justru tidak ada. Instrumen penilaian ditandatangani oleh instruktur dan atasan penilai tanpa ada tanda tangan siswa praktikan sebagai bukti kesepakatan ketiga belah pihak. Baik siswa maupun pihak penilai juga tidak diberi kesempatan menuliskan catatan atau tanggapan mereka terhadap hasil penilaian kinerja dalam instrumen penilaian kinerja.

Berbagai permasalahan tersebut mendorong peneliti untuk mengevaluasi kesesuaian sistem penilaian kinerja siswa SMK dalam pelaksanaan Prakerin di UPT-PK Singosari dengan standar. Alasan lain yang mendukung perlunya penelitian ini dilaksanakan adalah karena sistem penilaian kinerja yang dievaluasi pada penelitian sebelumnya masih terbatas pada sistem penilaian kinerja untuk karyawan/pegawai sebuah perusahaan/instansi, belum ada yang mengevaluasi sistem penilaian kinerja siswa SMK dalam pelaksanaan Prakerin di industri.

Penelitian bertujuan mengevaluasi program penilaian kinerja UPT-PK Singosari, yang meliputi: (1) input, yaitu penilai, siswa, instrumen penilaian kinerja, dan metode penilaian kinerja, (2) proses penilaian kinerja, dan (3) hasil penilaian kinerja.

Penentuan standar untuk setiap variabel didasarkan pada kajian teori dan temuan penelitian sebelumnya. Standar kualitas penilai kinerja, meliputi standar 
kompetensi, standar intelegensi, standar autoritas, standar hubungan dengan pihak yang dinilai, dan standar kepribadian (Suwatno, 2008: 81; Rivai, 2003: 309; Nasution, 2005: 51). Standar kualitas siswa yang dinilai kinerjanya, meliputi standar kompetensi dan standar kepribadian (Lahagu, 2010: 24; Feist, 2010: 35).

Standar kualitas instrumen penilaian kinerja, meliputi standar isi dan standar aspek yang dinilai (Rahadi, 2010:42; Lahagu, 2010:26). Standar kualitas metode penilaian kinerja, meliputi standar eksistensi, standar kesesuaian, dan standar jenis (Rothwell, 2008: 56; Rivai, 2008: 312). Standar kualitas proses penilaian kinerja, meliputi standar tujuan, standar metode, standar instrumen, standar pihak yang terlibat, standar periode, standar waktu, dan standar umpan balik (Sedarmayanti, 2010: 280; Mahardhika, 2012: 12; Kusumapraja, 2012: 15).

Adapun yang dimaksud standar di dalam penelitian ini adalah suatu norma atau persyaratan yang dapat menciptakan kriteria, proses, metode, dan teknis yang seragam. Standar yang diperoleh dari kajian teori dan temuan penelitian sebelumnya nantinya akan dibandingkan dengan temuan dan hasil penelitian, sehingga sesuai dengan tujuan penelitian yaitu untuk mengevaluasi kesesuaian antara kualitas penilai kinerja, siswa yang dinilai kinerjanya, instrumen penilaian, metode penilaian, proses penilaian, dan hasil penilaian kinerja dengan standar yang berlaku.

\section{METODE}

Penelitian ini adalah penelitian evaluatif dengan 3 tahapan penelitian, yaitu tahap: persiapan, pelaksanaan evaluasi, dan penyusunan hasil evaluasi. Variabel penelitian ini adalah 6 komponen sistem penilaian kinerja, meliputi: (1) instruktur sebagai penilai kinerja, (2) siswa yang dinilai kinerjanya, (3) instrumen penilaian, (4) metode penilaian, (5) proses penilaian, dan (6) hasil penilaian kinerja. Subjek dalam penelitian ini yaitu seluruh instruktur dan asisten instruktur Jurusan Listrik, UPT-PK Singosari sebagai pihak yang bertanggung jawab dalam penyusunan dan pelaksanaan sistem penilaian kinerja, yang seluruhnya berjumlah 9 orang.

Instrumen penelitian yaitu lembar angket dan lembar pengamatan dokumen. Lembar angket digunakan untuk mengumpulkan data variabel metode dan proses penilaian kinerja, ditujukan kepada seluruh instruktur dan asisten instruktur. Sedangkan, lembar pengamatan dokumen digunakan untuk mengumpulkan data variabel pihak penilai, pihak yang dinilai, instrumen penilaian, dan hasil penilaian kinerja. Data dianalisis secara deskriptif dengan bantuan aplikasi SPSS 17.0.

\section{HASIL}

Pihak penilai kinerja adalah seluruh instruktur dan asisten instruktur Jurusan Listrik, UPT-PK Singosari yang jumlahnya 9 orang. Berdasarkan hasil penelitian, dari 9 penilai kinerja, hanya 1 orang yang kualitasnya sangat sesuai standar, dengan persentase kesesuaian sebesar $85,90 \%$.

Sedangkan 5 orang lainnya memiliki kualitas yang sesuai standar, sehingga

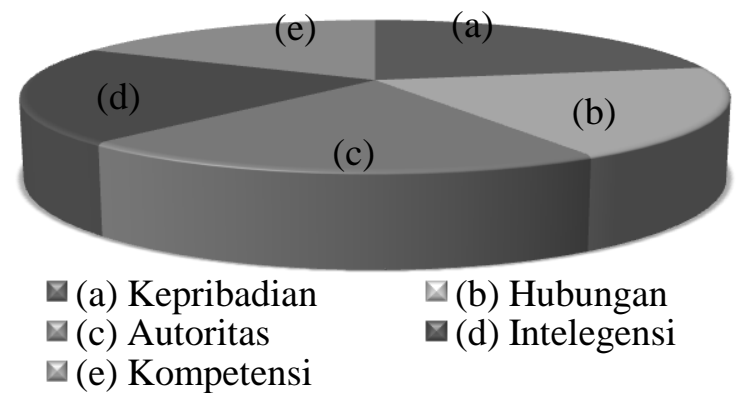

\section{Gambar 1. Diagram Pie Perbandingan Kualitas Pihak Penilai Kinerja}

perlu ditingkatkan atau minimal dipertahankan kualitasnya, dan 3 orang yang 
kualitasnya cukup sesuai standar perlu ditingkatkan lagi. Indikator yang memiliki persentase kesesuaian: (a) kepribadian $90,70 \%$ sangat tinggi, (b) hubungan $78,90 \%$ tinggi, (c) autoritas 83,80 \% tinggi, (d) intelegensi 84,30 tinggi, dan (e) kompetensi $71,90 \%$ cukup tinggi. Data tersebut tertera pada Gambar 1.

Oleh sebab itu, pihak penilai harus mempertahankan kepribadian yang sudah sangat baik tersebut, serta terus berupaya meningkatkan kompetensi individu. Rendahnya nilai kompetensi disebabkan karena nilai aspek teknis dan aspek non teknis yang diperoleh dari hasil penilaian kinerja instruktur dan asistennya masih belum maksimal.

Selain itu, kurangnya pengalaman mereka dalam mengikuti pelatihan penilaian kinerja, dan pengalaman meraih prestasi serta penghargaan bidang keahlian. Meskipun demikian, kualitas pihak penilai kinerja secara keseluruhan sudah sesuai standar, dengan persentase sebesar $77,17 \%$.

Pihak yang dinilai kinerjanya adalah siswa/siswi Kelas XI Multimedia SMK Merdeka Lawang yang sedang melaksanakan Prakerin di Jurusan Listrik, UPTPK Singosari pada saat penelitian dilakukan, berjumlah 14 anak. Berdasarkan hasil penelitian, kualitas siswa praktikan kurang sesuai standar, dengan persentase kesesuaian sebesar 46,80\%.

Indikator yang memiliki persentase kesesuaian: (a) kepribadian 67,30\% cukup tinggi. Sedangkan persentase untuk indikator (b) kompetensi 27,60\% sangat rendah. Data tersebut sebagaimana tertera pada Gambar 2.

Hasil penelitian juga menunjukkan bahwa dari 14 siswa, 78,50\% siswa kualitasnya kurang sesuai standar, dan $21,40 \%$ siswa lainnya kualitasnya sangat tidak sesuai standar. Hal tersebut dikarenakan nilai kompetensi siswa yang sangat rendah, sehingga mereka harus lebih meningkatkan kompetensi dengan lebih giat belajar. Begitu juga guru, sekolah, dan orang tua harus lebih memperhatikan pencapaian kompetensi anak didiknya. Rendahnya kompetensi siswa juga disebabkan oleh beberapa faktor, seperti hasil belajar yang rendah, kelelahan, lingkungan sekolah yang bising mengganggu belajar siswa, kondisi sosial ekonomi keluarga, dan kurangnya fasilitas belajar siswa di sekolah.

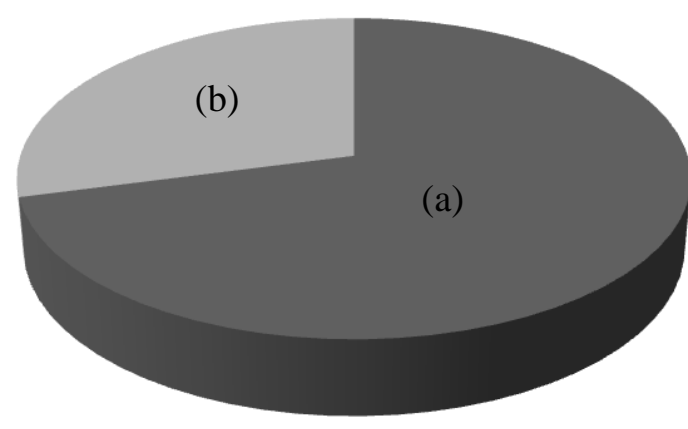

(a) Kepribadian $\quad$ (b) Kompetensi

\section{Gambar 2. Diagram Pie Perbandingan KualitasPihak yang Dinilai}

Adapun faktor internal dan eksternal yang berpengaruh pada keberhasilan Prakerin siswa. Faktor internal merupakan faktor yang berasal dari dalam diri, seperti pemahaman siswa mengenai tujuan dan manfaat Prakerin, kesiapan, serta keaktifan siswa dalam pelaksanaan Prakerin. Sedangkan, faktor eksternal adalah faktor di luar diri siswa, seperti pemahaman pembimbing industri terhadap pentingnya Prakerin bagi siswa, kesiapan pembimbing, dan kuantitas pembimbingan (Arif, 2014: 267).

Instrumen penilaian kinerja adalah lembar dokumen yang digunakan Jurusan Listrik, UPT-PK Singosari untuk mencatat hasil penilaian kinerja siswa praktikan. Berdasarkan hasil penelitian, dari 14 bagian instrumen penilaian kinerja terstandar, $64,20 \%$ bagian terpenuhi. Hal ini berarti $35,70 \%$ bagian instrumen yang tidak terpenuhi, yaitu petunjuk penilaian, kriteria penilaian, catatan penilai, tang- 
gapan siswa, dan tanda tangan siswa praktikan.

Kualitas instrumen penilaian kinerja secara keseluruhan sudah cukup sesuai standar, dengan persentase kesesuaian sebesar $64,29 \%$. Jadi, instrumen dapat tetap digunakan namun harus direvisi terlebih dahulu dengan melengkapi bagian-bagian yang belum terpenuhi tersebut.

Metode penilaian kinerja adalah cara atau teknik yang digunakan Jurusan Listrik, UPT-PK Singosari dalam melakukan penilaian kinerja siswa praktikan. Berdasarkan hasil penelitian, indikator: (a) jenis 77,80\% baik, (b) eksistensi 91,70\% sangat baik, dan (c) kesesuaian 74,40\% cukup baik. Data tersebut tertera pada Gambar 3.

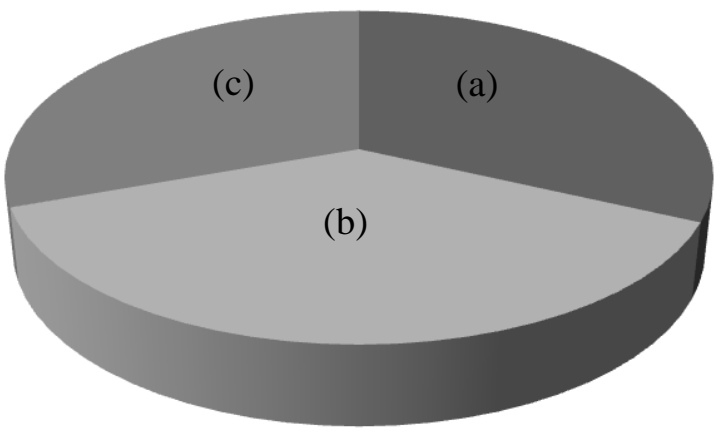

(a) Jenis $\square$ (b) Eksistensi $\square$ (c) Kesesuaian

\section{Gambar 3. Diagram Pie Perbandingan Kualitas Metode Penilaian}

Kurang maksimalnya nilai kesesuaian karena penyusunan metode penilaian kinerja belum disesuaikan dengan kebutuhan industri di masa depan, serta kebutuhan siswa saat ini dan masa depan. Penyusunan metode juga belum sepenuhnya disesuaikan dengan tujuan penilaian kinerja. Hal ini karena pihak UPT-PK Singosari belum pernah mengkaji secara mendalam mengenai kesesuain metode dengan tujuan penilaian kinerja.

Jenis metode penilaian yang digunakan sudah cukup variatif, yaitu tes tulis, lisan, praktik kerja, portofolio, dan observasi. Hanya saja implementasi dan sosia- lisasinya belum terlaksana maksimal, sehingga masih banyak siswa praktikan yang tidak tahu mengenai metode penilaian kinerja yang digunakan.

Kualitas metode penilaian kinerja secara keseluruhan sudah sesuai standar, dengan persentase kesesuaian sebesar $81,11 \%$, sehingga metode penilaian kinerja dapat tetap digunakan, namun perlu dikaji ulang kesesuaian metode dengan tujuan maupun dengan kebutuhan saat ini dan masa depan.

Proses penilaian kinerja adalah serangkaian kegiatan atau prosedur penilaian kinerja yang diterapkan UPT-PK Singosari dalam menilai kinerja siswa praktikan. Berdasarkan hasil penelitian, kualitas proses penilaian kinerja UPT-PK Singosari secara keseluruhan sudah sesuai standar, dengan persentase kesesuaian se-

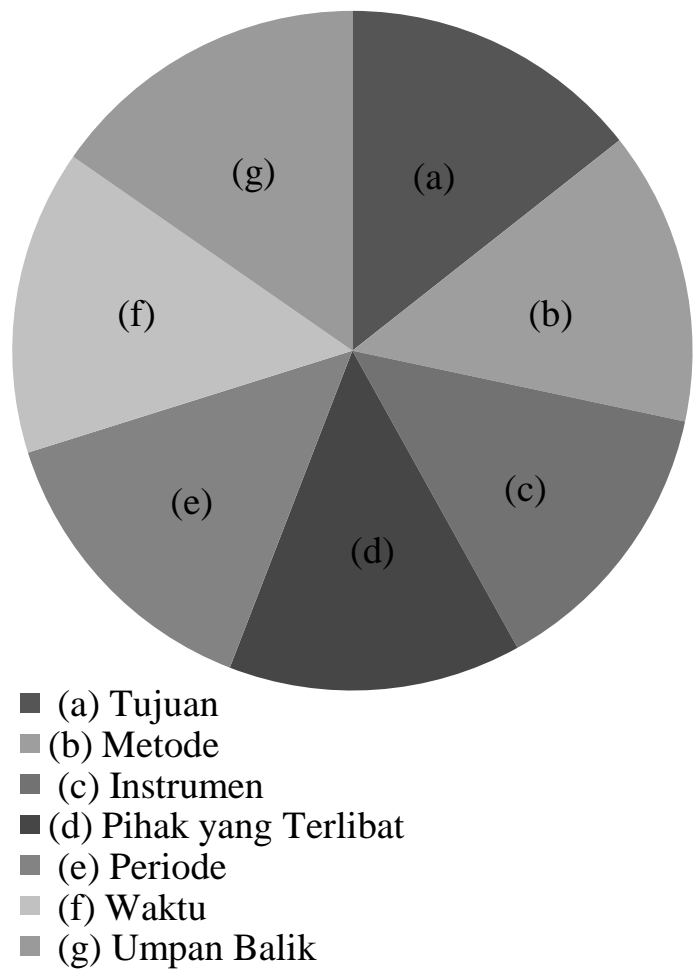

\section{Gambar 4. Diagram Pie Perbandingan Kualitas Proses Penilaian Kinerja}

besar $75,00 \%$, jadi dapat tetap dilaksanakan, namun perlu dikaji ulang demi peningkatan kualitas proses penilaiannya. 
Berdasarkan hasil penelitian indikator: (a) tujuan $76,40 \%$, (b) metode $74,20 \%$, (c) instrumen $72,20 \%$, (d) pihak yang terlibat $74,10 \%$, (e) periode $75,90 \%$, (f) waktu $77,10 \%$, dan (g) umpan balik $81,50 \%$. Data tersebut tertera pada Gambar 4.

Indikator instrumen penilaian kinerja menghasilkan nilai persentase paling rendah karena sosialisasi instrumen belum maksimal. Penggunaan instrumen penilaian juga masih belum konsisten. Kurangnya sosialisasi instrumen penilaian kinerja kepada siswa menyebabkan mereka tidak mengetahui aspek apa saja yang akan dinilai dari diri mereka, yang tentu berpengaruh pada hasil penilaiannya. Selain sosialisasi instrumen, sosialisasi mengenai periode dan waktu penilaian kinerja juga jarang dilaksanakan. Hal tersebut karena UPT-PK Singosari belum memiliki pedoman penilaian yang tertulis secara baku sebagai acuan dalam keseluruhan proses penilaian kinerja. UPT-PK Singosari perlu menyusun pedoman penilaian kinerja siswa praktikan untuk menghindari perbedaan persepsi antar pihak penilai kinerja.

Hasil penilaian kinerja adalah nilai prakerin siswa SMK Merdeka Lawang setelah melaksanakan Prakerin di Jurusan Listrik, UPT-PK Singosari selama 3 bulan. Berdasarkan hasil penelitian, kualitas hasil penilaian kinerja siswa praktikan sangat sesuai standar, dengan persentase kesesuaian sebesar 100,00\%. Hal ini disebabkan oleh tingginya skor aspek teknis dan aspek non teknis siswa yaitu 90 (nilai 3 aspek teknis dan 3 aspek non teknis siswa > 80). Begitu juga dengan rerata nilai keseluruhan sangat tinggi yaitu $(30>80)$.

Kualitas hasil penilaian kinerja yang sudah sangat sesuai standar ini harus terus dipertahankan seiring berupaya untuk meningkatkannya. Salah satu faktor yang menyebabkan tingginya nilai aspek tek- nis siswa adalah karena siswa dilatih dan dibimbing dengan sungguh-sungguh oleh instruktur maupun asisten instruktur untuk menguasai aspek teknis tersebut. Aspek teknis yang diperoleh juga banyak yang belum pernah diperoleh siswa selama di bangku sekolah, sehingga mereka antusias untuk mempelajari hal baru. Selain itu, sarana prasarana praktik kerja yang tersedia di UPT-PK Singosari lebih lengkap dari pada yang ada di sekolah mereka. Hal tersebut yang menjadikan mereka menggunakan waktu dan kesempatan sebaik-baiknya dalam setiap kegiatan praktik kerja di UPT-PK Singosari.

Sedangkan tingginya nilai aspek non teknis siswa selama Prakerin di UPT-PK Singosari diantaranya disebabkan oleh keseriusan instruktur dan asistennya dalam memberi arahan serta bimbingan kepada siswa praktikan, baik sebelum Prakerin, saat praktik kerja, maupun menjelang berakhirnya Prakerin. Tata tertib yang ada ikut memberi kontribusi terhadap aspek non teknis siswa, terutama dalam hal kedisiplinan, sopan santun, dan kehadiran.

\section{PEMBAHASAN}

Berdasarkan hasil analisis, diperoleh bahwa kualitas penilai kinerja UPT-PK Singosari adalah baik dan sudah sesuai standar, yang dibuktikan dengan nilai persentase sebesar 77,17\%. Hal ini disebabkan karena kepribadian pihak penilai kinerja yang sangat baik 90,70\%, intelegensi tinggi $84,30 \%$, autoritas tinggi $83,80 \%$, serta intensitas hubungan dengan siswa praktikan dekat $78,90 \%$.

Kepribadian dipengaruhi oleh 3 faktor, yaitu faktor biologis, sosial, dan kebudayaan (Purwanto, 2010: 160-164). Berdasarkan pengamatan peneliti, faktor sosial terutama lingkungan sekitar pihak penilai kinerja cukup baik. Ini dibuktikan dengan lingkungan keluarga pihak pe- 
nilai kinerja yang sangat mementingkan dan mengedepankan pendidikan serta pekerjaan.

Selain kepribadian, kualitas pihak penilai kinerja UPT-PK Singosari baik, karena tingkat intelegensi pihak penilai kinerja yang tinggi. Hal ini dibuktikan dari hasil penelitian yang menunjukkan bahwa kemampuan penalaran dan pengambilan keputusan pihak penilai kinerja sangat tinggi, serta kemampuan berpikir kritis dan pemecahan masalah yang tinggi.

Peneliti berpendapat bahwa tingkat intelegensi pihak penilai kinerja dapat mempengaruhi kualitas diri mereka, yang tercermin dalam hasil penilaian kinerja. Pendapat tersebut relevan dengan penelitian Trihandini (2005) menyatakan bahwa kecerdasan intelektual mempunyai pengaruh positif terhadap kinerja karyawan dengan nilai probabilitas sebesar $0,004$ ( $\mathrm{p}<0,05)$, semakin baik kecerdasan intelektual karyawan pada Hotel Horison Semarang maka akan semakin baik kinerja karyawan. Selain tingkat pendidikan, Slameto (2010: 131) menjelaskan bahwa intelegensi juga dipengaruhi oleh beberapa faktor yaitu keturunan, latar belakang sosial ekonomi, lingkungan, kondisi fisik, dan iklim emosi.

Baiknya kualitas pihak penilai kinerja Jurusan Listrik UPT-PK Singosari juga disebabkan oleh dekatnya hubungan pihak penilai dengan siswa yang dinilai yang ditunjukkan dari intensitas tatap muka mereka dengan siswa praktikan dan presensi. Hal ini sesuai teori Mathis dan Jackson (2006: 387) bahwa yang bisa menjadi penilai kinerja adalah siapapun yang mengetahui dengan baik kinerja pihak yang dinilai.

Rendahnya kompetensi siswa praktikan dikarenakan belum maksimalnya hasil belajar siswa pada mata pelajaran produktif di sekolah. Terbukti dari hasil pengamatan peneliti terhadap nilai rapor siswa di sekolah, hampir seluruh siswa memperoleh nilai $<80$ dan hanya ada 1 siswa yang nilainya $>80$, itupun nilainya hanya 82 . Selisih antara nilai seluruh siswa pada mata pelajaran produktif di sekolah dengan KKM (76) sangatlah tipis.

Rendahnya hasil belajar siswa pada mata pelajaran produktif juga disebabkan karena minimnya sarana prasarana sekolah, media belajar, dan tenaga pengajar. Purwanto (2010: 105) menjelaskan bahwa sekolah yang cukup memiliki alat-alat dan perlengkapan yang diperlukan untuk belajar dapat mempermudah dan mempercepat belajar siswa. Hal ini relevan dengan penelitian Supardi (2010) yang menyimpulkan bahwa terdapat pengaruh yang signifikan antara pengunaan media pembelajaran dan minat belajar terhadap hasil belajar siswa, dengan nilai $F_{h}=4,93$ dan nilai Sig. $=0,03$.

Menurut teori Slameto (2010: 77), tempat belajar harusnya tenang dan tidak diganggu dengan perangsang-perangsang dari sekitar, karena belajar membutuhkan konsentrasi yang sangat tinggi. Teori tersebut bertolak belakang dengan kondisi lingkungan belajar siswa yang bising, dekat dengan jalan raya antar kota, sehingga dapat mempengaruhi konsentrasi belajar siswa. Relevan dengan penelitian Wahyuningsih (2013) bahwa lingkungan sekolah berpengaruh positif dan signifikan terhadap prestasi belajar yang ditunjukkan dengan nilai $\mathrm{RX}_{1} \mathrm{Y}=0,496, \mathrm{R}_{2}$ sebesar $0,246, \mathrm{t}_{\text {hitung }}>\mathrm{t}_{\text {tabel }}$ yaitu 3,470 > 1,685 .

Kelelahan juga menjadi salah satu faktor yang mempengaruhi belajar siswa. Hal ini dikarenakan sebagian besar siswa praktikan adalah anak yatim atau anak yatim piatu yang hidup dan tinggal di panti asuhan dekat sekolah. Kegiatan panti asuhan yang sangat padat dan banyak, seperti piket kebersihan, mengaji, belajar, dan sebagainya berakibat pada lelahnya siswa. Kelelahan berpengaruh pada belajar siswa, sehingga agar siswa da- 
pat belajar dengan baik haruslah menghindari dari kelelahan dan jangan sampai terjadi kelelahan (Slameto, 2010: 60).

Keterampilan tambahan yang dimiliki siswa masih sedikit, hanya 1 atau 2 keterampilan tambahan saja. Hal ini disebabkan karena belum adanya wadah atau media belajar siswa untuk mengasah dan mengembangkan keterampilan, khususnya di bidang multimedia. Penelitian Sayoga (2009) menjelaskan bahwa ada hubungan antara keterampilan menggunakan multimedia dengan prestasi belajar produktif di SMK Muhammadiyah $3 \mathrm{Su}$ rakarta ( $r_{\text {hitung }}>r_{\text {tabel }}$ atau 0,62 $>0,25$ pada taraf signifikansi 5,00\%) dan ada hubungan antara kreativitas siswa dengan prestasi belajar produktif di SMK Muhammadiyah 3 Surakarta $\left(r_{\text {hitung }}>r_{\text {tabel }}\right.$ atau $0,75>0,25$ pada taraf signifikansi $5,00 \%)$.

Bagian instrumen penilaian kinerja yang terpenuhi, yaitu nama instansi, identitas pihak yang dinilai (siswa praktikan), identitas penilai, masa periode penilaian, aspek penilaian kinerja, tanda tangan penilai, tanda tangan atasan penilai, aspek teknis, dan aspek non teknis. Sedangkan, 5 bagian instrumen yang tidak terpenuhi, yaitu petunjuk penilaian, kriteria penilaian, catatan penilai, tanggapan pihak yang dinilai, dan tanda tangan siswa praktikan.

Bagian instrumen yang tidak terpenuhi, seperti petunjuk penilaian kinerja seharusnya ditambahkan dalam instrumen penilaian kinerja UPT-PK Singosari, karena petunjuk merupakan pedoman dalam kegiatan menilai kinerja siswa praktikan. Seorang penilai kinerja dapat mengetahui dan memahami prosedur penilaian kinerja siswa praktikan dengan membaca petunjuk penilaian yang ada di dalam instrumen. Dengan demikian, cara menilai dan mengisi instrumen harus dijelaskan terlebih dahulu sebelum penilai kinerja melakukan penilaian.

Jika petunjuk penilaian tidak ada di dalam instrumen penilaian, maka bisa jadi pihak penilai mengalami kesulitan atau kurang memahami cara mengisi dan menilai siswa praktikan. Hal ini dapat mempengaruhi keakuratan hasil penilaian kinerja siswa praktikan, hanya gara-gara pihak penilai tidak tahu bagaimana cara mengisi instrumen penilaian tersebut.

Bagian instrumen lain yang seharusnya ada di dalam instrumen adalah kriteria penilaian kinerja. Kriteria penilaian ini sangat penting untuk menafsirkan nilai siswa ke dalam bentuk huruf, maupun sebaliknya. Hal ini sesuai dengan teori Soeprihanto (2009: 25) yang mengatakan bahwa aspek-aspek penilaian kinerja dapat dinilai dengan kriteria penilaian tertentu. Jika, kriteria penilaian kinerja tidak ada di dalam instrumen penilaian kinerja, pihak penilai pasti mengalami kesulitan dalam menentukan tingkat prestasi kerja siswa praktikan, apakah kinerjanya sangat baik, baik, cukup, sedang, atau kurang. Kesalahan penafsiran prestasi kerja siswa dapat berakibat fatal, karena sangat merugikan siswa praktikan. Untuk itu, kriteria penilaian sangat penting dan harus ada di dalam instrumen penilaian kinerja di UPT-PK Singosari.

Eksistensi metode penilaian kinerja di UPT-PK Singosari mendapat respon yang sangat baik dari para responden. Hal ini dikarenakan kondisi sebenarnya di UPT-PK Singosari memang sudah memiliki metode penilaian khusus untuk menilai kinerja siswa praktikan. Penerapan metode tersebut sudah berjalan selama lebih dari 3 tahun, hanya saja implementasinya belum maksimal.

Pihak UPT-PK Singosari sangat mendukung penyusunan metode penilaian kinerja khusus untuk menilai kinerja siswa praktikan, baik di UPT-PK Singosari maupun di industri-industri lain yang menjadi tempat prakerin siswa SMK. Pihak UPT-PK Singosari cukup sering mengadakan diskusi atau musyawarah dengan pihak sekolah untuk menentukan metode penilaian yang paling tepat untuk 
menilai kinerja siswa praktikan. Penyusunan metode penilaian kinerja sangat penting bagi setiap industri atau instansi mitra sekolah, apalagi jika belum pernah dirancang sebelumnya.

Indikator jenis metode penilaian kinerja mendapat respon yang baik dari para responden, karena jenis metode penilaian kinerja yang digunakan oleh UPT-PK Singosari dalam menilai kinerja siswa praktikan sudah cukup bervariasi. Seluruhnya ada 5 jenis metode penilaian kinerja yang digunakan, yaitu tes tulis, tes lisan, portofolio, unjuk kerja, dan observasi.

Meskipun terkadang implementasinya kurang maksimal karena harus selalu disesuaikan dengan karakter siswa dan situasi kondisi pada saat itu. Hal ini sesuai dengan teori Rivai (2008) bahwa metode penilaian kinerja yang digunakan untuk mengukur kinerja seseorang haruslah bervariasi dan konsisten, artinya tidak hanya menggunakan satu metode saja dan tidak berubah-ubah.

Meskipun implementasi metode penilaian kinerja belum dapat maksimal, namun UPT-PK Singosari sudah cukup konsisten dalam penggunaan jenis metode penilaian kinerja. Konsistensi ini sangat baik, karena akan memudahkan pihak penilai kinerja dalam melaksanakan penilaian. Siswa praktikan tidak akan merasa dibingungkan dengan berubahubahnya jenis metode penilaian yang digunakan.

Beberapa hal yang menyebabkan indikator kesesuain metode mendapat respon yang cukup baik adalah karena meskipun penyusunan metodenya sudah sangat matang, seharusnya perlu diadakan riset untuk mengungkap apakah metode penilaian kinerja yang dirancang sudah mencapai tujuan penilaian kinerja. Pembelajaran di tempat kerja akan efektif jika tujuan Prakerin ditetapkan berdasarkan hasil negosiasi penyelenggara dengan industri, sehingga program Prakerin relevan dengan perkembangan dan kondisi industri (Sintawati dan Sudjimat, 2014: 50).

Implementasi kegiatan sosialisasi metode penilaian kinerja di UPT-PK Singosari belum maksimal. Kegiatan sosialisasi ini sangat penting, khususnya bagi pihak-pihak yang terlibat langsung dalam proses penilaian kinerja, seperti instruktur, asisten instruktur, maupun siswa praktikan. Hal ini sesuai dengan teori Sedarmayanti (2010: 119) bahwa stabilitas organisasi akan dapat meningkat melalui sosialisasi. Itulah sebabnya penting bagi UPT-PK Singosari untuk mensosialisasikan metode penilaian kinerja dan hal lainnya kepada siswa praktikan sebelum mereka memulai Prakerin.

Tanpa adanya sosialisasi siswa kurang bersungguh-sungguh dalam melaksanakan Prakerin yang dapat berakibat pada rendahnya nilai aspek teknis dan non teknis siswa. Kesimpulannya, sebaik apapun metode penilaian yang disusun harus disesuaikan dengan tujuan penilaian kinerja, agar tujuan dapat tercapai dengan maksimal. Sedangkan untuk membuktikan kesesuaian tersebut harus diadakan riset atau penelitian mengenai tingkat ketercapaian tujuan penilaian kinerja.

Indikator tujuan, periode, waktu, dan umpan balik mendapat respon yang baik dari para responden, dikarenakan tujuan sistem penilaian kinerja di industri sudah cukup spesifik untuk hal-hal yang berhubungan dengan pekerjaan, penyusunannya berdasarkan kajian secara mendalam, dan 70,00\% mengarah pada pekerjaan.

Artinya, tujuan sistem penilaian kinerja di UPT-PK Singosari adalah untuk mengukur kemampuan dan profesionalitas siswa praktikan pada bidang keahlian mereka yang tentunya kemampuan dan profesionalitas tersebut akan bermanfaat bagi siswa dalam pekerjaan mereka di masa mendatang. Selain itu, kegiatan mengukur kemampuan dan profesional siswa praktikan berfungsi sebagai dorongan untuk lebih meningkatkan kuali- 
tas dan prestasi kerja mereka selama maupun setelah Prakerin.

Tujuan sistem penilaian kinerja UPT-PK Singosari juga sudah disesuaikan dengan kebutuhan industri saat ini, karena penyusunannya dikaji secara mendalam dan melalui beberapa riset. Tujuan penilaian kinerja di UPT-PK Singosari harus selalu mengikuti perkembangan kebutuhan pasar kerja saat ini. Bisa jadi, tujuan penilaian kinerja UPT-PK Singosari bukan lagi untuk mengukur kemampuan dan profesionalisme siswa praktikan, tetapi juga untuk memprediksi karir siswa di masa mendatang.

Periode dan waktu penilaian kinerja di UPT-PK Singosari sudah baik, karena penilaian kinerja dilaksanakan empat kali dalam satu bulan, yaitu setiap minggu diadakan penilaian kinerja. Sosialisasi terhadap periode dan waktu penilaian kinerja juga sering dilaksanakan, yaitu setiap sebelum kegiatan penilaian kinerja.

Namun, tidak dipungkiri bahwa implementasinya masih kurang maksimal, artinya pelaksanaan sosialisasinya belum rutin dan terkadang tidak dilaksanakan. Hal ini tidak sesuai dengan teori Mahardhika (2012) bahwa waktu penilaian kinerja harus jelas, artinya waktu penilaian kinerja di UPT-PK Singosari harus rutin dilaksanakan. Meskipun demikian, secara keseluruhan periode dan waktu penilaian kinerja di UPT-PK Singosari sudah baik.

Indikator proses penilaian kinerja lainnya yang mendapat penilaian cukup baik dari para responden, yaitu indikator pihak yang terlibat. Pihak yang ditunjuk untuk menilai kinerja siswa merupakan orang yang cukup kompeten dan sesuai dengan bidang keahlian siswa praktikan. Pihak penilai terpilih juga merupakan orang yang jujur, adil, dan tidak diskriminatif. Hal ini sesuai dengan teori Suwatno (2008: 81) bahwa penilai haruslah orang yang jujur, adil, dan objektif.

Pelatihan yang diadakan oleh UPTPK Singosari untuk penilai juga masih jarang, yaitu setiap enam bulan sekali.
Itupun bukan pelatihan khusus penilaian kinerja semacam RET (Rating Error Training) atau RAT (Rating Accuracy Training), hanya pelatihan bidang keahlian dan umum. Hal ini bertolak belakang dengan teori Sedarmayanti (2010: 276) yang mengatakan bahwa pihak penilai kinerja harus mendapatkan pelatihan penilaian kinerja.

Selama tiga bulan siswa melaksanakan Prakerin di UPT-PK Singosari, ada sembilan aspek teknis yang dinilai oleh penilai UPT-PK Singosari, khususnya bidang keahlian multimedia. Beberapa faktor yang menyebabkan tingginya nilai siswa pada aspek teknis tersebut diantaranya adalah setiap siswa dilatih dan dibimbing dengan sungguh-sungguh oleh instruktur maupun asisten instruktur untuk menguasai sembilan aspek teknis tersebut.

Bimbingan yang baik dari para instruktur dan asisten instruktur di UPT-PK Singosari tentu mempengaruhi sikap siswa selama Prakerin yang tentu dapat mempengaruhi kepribadian mereka. Aspek teknis yang diperoleh juga banyak yang belum pernah diperoleh siswa selama di bangku sekolah, sehingga mereka antusias untuk mempelajari hal baru.

Slameto (2010: 56) menjelaskan bahwa untuk menjamin hasil belajar siswa yang baik, maka mereka harus mempunyai perhatian terhadap bahan yang dipelajarinya. Jika bahan pelajaran tidak dapat menarik perhatian siswa, maka akan timbul kebosanan sehingga mereka kurang menyukai bahan pelajaran tersebut. Jadi, agar siswa dapat belajar dengan baik, instruktur maupun asisten instruktur harus mengusahakan untuk menyediakan bahan pelajaran yang selalu menarik perhatian dengan cara mengusahakan pelajaran yang sesuai dengan hobi atau bakat siswa.

Selain itu, sarana prasarana praktik kerja yang tersedia di UPT-PK Singosari lebih lengkap dari pada yang ada di sekolah mereka. Hal tersebut yang menja- 
dikan mereka menggunakan waktu dan kesempatan sebaik-baiknya dalam setiap kegiatan praktik kerja di UPT-PK Singosari. Tingginya nilai aspek non teknis siswa selama Prakerin di UPT-PK Singosari diantaranya disebabkan oleh keseriusan instruktur dan asistennya dalam memberi arahan kepada siswa praktikan. Tata tertib juga ikut memberikan kontribusi terhadap aspek non teknis siswa, terutama dalam hal kedisiplinan, sopan santun, dan kehadiran.

Beberapa poin yang ada dalam tata tertib menjadikan siswa praktikan memiliki kedisiplinan dan etika yang baik selama Prakerin di UPT-PK Singosari. Demikian juga dengan aspek non teknis, seperti tanggung jawab, kreativitas, dan kerjasama akan selalu dipantau oleh instruktur maupun asisten instruktur. Beban praktik kerja dan tuntutan kedisiplinan mampu memberikan pengajaran secara tidak langsung kepada siswa praktikan untuk bertanggung jawab, baik kepada diri sendiri maupun orang lain.

\section{SIMPULAN DAN SARAN}

Bertolak dari temuan penelitian dan pembahasan, hasil penelitian dapat disimpulkan sebagai berikut. Pertama, kualitas input meliputi: (1) kualitas penilai kinerja UPT-PK Singosari sudah sesuai standar, (2) kualitas siswa (siswa praktikan) UPTPK Singosari kurang sesuai standar, (3) kualitas instrumen penilaian kinerja UPT-PK Singosari cukup sesuai standar, dan (4) kualitas metode penilaian kinerja yang digunakan UPT-PK Singosari untuk menilai siswa praktikan sudah sesuai standar. Kedua, kualitas proses penilaian kinerja yang diterapkan UPT-PK Singosari sesuai dengan standar. Ketiga, kualitas hasil penilaian kinerja siswa praktikan UPT-PK Singosari sangat sesuai dengan standar.

Berdasarkan simpulan di atas, maka saran yang diajukan dirumuskan sebagai berikut. Pemangku kebijakan UPT-PK Singosari disarankan untuk tetap menggunakan sistem penilaian kinerja yang berlaku, hanya saja perlu merevisi dan mengkaji ulang sistem berdasarkan hasil penelitian ini. Pihak penilai kinerja disarankan untuk lebih giat mengikuti pelatihan bidang keahlian tingkat nasional, melaksanakan sosialisasi dengan rutin, dan lebih serius menekuni bidangnya agar memperoleh penghargaan.

Siswa disarankan meningkatkan hasil belajarnya, terutama mata pelajaran produktif, meningkatkan minat dan motivasi, membuat penjadwalan belajar, dan istirahat cukup agar konsentrasi belajar bagus. Pihak penyusun instrumen penilaian kinerja disarankan untuk mengikuti pelatihan khusus penyusunan instrumen penilaian kinerja, serta melakukan uji keabsahan sebelum instrumen digunakan.

Pihak perancang metode disarankan untuk tetap menggunakan metode lama dengan menggabungkan metode-metode baru, penyusunannya harus dimusyawarahkan dengan sekolah. Pihak sekolah dan industri disarankan untuk dapat bekerjasama dengan UPT-PK Singosari, orangtua, dan siswa praktikan untuk menciptakan sebuah sistem penilaian kinerja yang handal dan efektif.

\section{DAFTAR RUJUKAN}

Ambarwati. 2002. Managing Productive Performance Appraisal: Sebuah Upaya Menjawab Kebutuhan Penilaian Kinerja Karyawan yang Bebas KKN. Jurnal Portal, (Online), 1(7): 93-107, (http://www.journal.uii.ac. id, diakses 22 Maret 2012).

Arif, U. 2014. Evaluasi Pelaksanaan Praktik Kerja Industri Peserta Didik Program Keahlian Teknik Otomotif SMK Giripuro Sumpiuh. Jurnal Pendidikan Vokasi, 4(2): 262-270.

Depdiknas. 2004. Kurikulum SMK Edisi 2004. Jakarta: Depdiknas. 
Feist, J. 2010. Teori Kepribadian. Jakarta: Salemba Humanika.

Kusumapraja, R. 2012. Manajemen SDM. Artikel tidak diterbitkan. Jakarta: Universitas Indonesia.

Lahagu, A. 2010. Pengaruh Pemahaman Konsep dan Intensitas Pengalaman Membimbing Prakerin terhadap Kemampuan Guru SMK Swasta Kristen BNKP Gunugsitoli, Kabupaten Nias. Tesis tidak diterbitkan. Bandung: Universitas Pendidikan Indonesia.

Mahardhika, G. 2012. Kinerja dan Penilaian Prestasi. Artikel tidak diterbitkan. Bengkulu: Universitas Muhammadiyah.

Mangkunegara, A.P. 2010. Evaluasi Kinerja SDM. Bandung: Refika Aditama.

Mathis, R. \& Jackson, J. 2006. Human Resource Management (Edisi Terjemahan). Jakarta: Salemba Empat.

Nasution, H. 2005. Performance Appraisal. Artikel tidak diterbitkan. Sumatra Utara: USU.

Purwanto, N. 2010. Psikologi Pendidikan. Bandung: Remaja Rosdakarya.

Rahadi, R. 2010. Manajemen Kinerja Sumber Daya Manusia. Malang: Tunggal Mandiri Publishing.

Rivai, V. 2008. Performa Appraisal. Jakarta: Rajawali Pers.

Rothwell, W. 2008. Mastering the Instructional Design Process: a Systematic Approach $4^{\text {th }}$ Edition. New York: John Wiley \& Sons, Inc.

Sayoga, S. 2009. Hubungan antara Kemampuan Awal, Kreativitas Siswa dan Keterampilan menggunakan Multimedia dengan Prestasi Belajar Mata Pelajaran Produktif. Tesis tidak diterbitkan. Surakarta: Universitas Negeri Surakarta.
Sedarmayanti. 2010. Manajemen Sumber Daya Manusia. Bandung: Refika Aditama.

Sintawati, E. \& Sudjimat, D.A. 2014. Evaluasi Program Praktik Kerja Industri Mahasiswa Program Studi Tata Busana Jurusan Teknologi Industri Fakultas Teknik Universitas Negeri Malang Berdasarkan CIPP. Jurnal Teknologi dan Kejuruan, 37(1): 49-64.

Slameto. 2010. Belajar dan Faktor-faktor yang Mempengaruhinya. Jakarta: Rineka Cipta.

Soeprihanto, J. 2009. Penilaian Kinerja dan Pengembangan Karyawan (Edisi 1). Yogyakarta: BPFE Yogyakarta.

Supardi. 2010. Pengaruh Media Pembelajaran dan Minat Belajar terhadap Hasil Belajar Fisika. Jurnal Formatif, (Online), 2(1): 71-81, (http:// www.portal. kopertis3. or.id, diakses 15 Mei 2013).

Suwatno. 2008. Pengantar Manajemen Sumber Daya Manusia. Bandung: FPIPS Universitas Pendidikan Indonesia.

Trihandini, F. 2005. Analisis Pengaruh Kecerdasan Intelektual, Kecerdasan Emosi, dan Kecerdasan Spiritual terhadap Kinerja Karyawan. Tesis tidak diterbitkan. Semarang: Universitas Diponegoro.

Wahyuningsih, S. 2013. Pengaruh Lingkungan Sekolah dan Kebiasaan Belajar terhadap Prestasi Belajar Akuntansi Siswa Kelas XI IPS SMA Negeri 1 Srandakan. Jurnal Kajian Pendidikan Akuntansi Indonesia, 2(1): 137-160. 